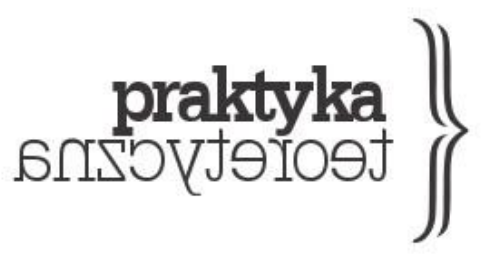

ISSN 2081-8130

DOI: $10.14746 /$ prt.2018.1.6 www.praktykateoretyczna.pl

\title{
A PATH TO A COUNTERMOVEMENT? FORMS OF INTEGRATION IN POLISH CONSUMER COOPERATIVES
}

\author{
ALEKSANDRA BILEWICZ
}

\begin{abstract}
This paper discusses Polish consumer cooperatives in terms of the embedded economy as understood by Karl Polanyi. The author compares today's "new" cooperatives, or informal groups of consumers that have been emerging in Poland since 2010, with the "old" consumer cooperative movement that existed between 1906 and 1939, as represented mainly by the "Społem" consumer cooperative union. Following Polanyi's understanding of the relationship between human economy and social institutions, I analyse reciprocity and redistribution as forms of economic integration in past and present cooperatives. Although the "new" cooperatives refer to the prewar cooperative traditions, their structure and economic operation differ vastly from the original model. I argue that the present structure of consumer cooperatives does not provide a base for symmetry and centricity - "supporting structures" for reciprocity and redistribution - although some of the new cooperatives do offer solutions for those deficits. This paper also discusses the nature of class barriers in the contemporary and historical consumer-cooperative movement, and relates this issue to Polanyian notions of countermovement and class interest.
\end{abstract}

Keywords: consumer cooperatives, embedded economy, forms of economic integration, reciprocity, countermovement, Karl Polanyi. 


\section{Introduction}

"We will abolish capitalism with this carrot" - read a slogan on a website of the first new consumer cooperative in Poland, Warszawska Kooperatywa Spożywcza, which was established in 2010. Unusual as those words may seem, they represent the way in which the creators of this informal consumer groups, organised to buy produce directly from farmers, referred to the original ideas behind the consumer cooperative movement - the idea to gradually replace the capitalist system by democratically organized associations of consumers. Most of the new cooperatives declare that they strive for "a more just, democratic and environmentally friendly economy" and for democratic, consensually governed entities. ${ }^{1}$ These groups have been emerging over the past eight years (i.e. since 2010). Overall, there have been over thirty attempts to form consumer cooperatives all over the country. However, not all of them survive the first years or even months.

The relationship of the new consumer cooperatives with the cooperative legacy, especially with the rich tradition of consumer cooperatives in Poland, which formed one of the largest and strongest Polish social movements prior to the Second World War (ChyraRolicz 1985, 1992), is a complex issue that I found especially worth investigating due to the fact that the new cooperatives promise to revive the democratic spirit of the once strong social movement. After 1945, cooperatives in Poland were delegitimised as a result of their incorporation into the Communist state's planned economy, resulting in a loss of autonomy of the cooperatives (Brodziński 1999). Leaders of today's cooperatives refer to the "real" or "original" democratic-cooperative traditions that thrived in Poland before 1939, but the new consumer groups that identify as "cooperatives" differ vastly from their pre-war predecessors.

The possibility of reviving the old cooperative model, born during the industrial revolution as a response to the disastrous situation of workers, should be interpreted as rather illusory in the post-industrial age. However, it must be emphasised that today's activists do not understand this revival literally. Indeed, the structure and aims of the new movement are quite different. I have found it fruitful to take seriously this declared connection with the past, by tracking the structural and ideological differences between the "old" consumer cooperatives that traced their roots to the 1860s and the new groups that are partly grounded in anarchist-inspired currents in the "newest social movements" (see Day 2005). In this article, when referring to the old cooperatives, I limit the scope of my comparison to

1 A slogan coined by a pioneering cooperative in Warsaw that is now found on websites of other cooperatives also. See the website of the Warsaw Consumer Cooperative (established in 2010): http://www.wks.waw.pl/kim-jestesmy/ (accessed 17/11/2016) and Krakowska Kooperatywa Spożywcza: http://kooperatywakrak.pl/ (accessed 17/11/2016). 
the Union of Consumer Cooperatives of the Polish Republic Spotem ${ }^{2}$ (which I henceforth refer to simply as Spotem, which means "together"), the largest cooperative union in the country during the interwar period. Established in 1911 in Warsaw as a local cooperative union (Warszawski Związek Stowarzyszeń Spożywczych), it was transformed into a national organisation after Poland regained independence in 1918.

My interest in the practice of consumer cooperatives lies in the ideas that they generally share about the economy, most notably about food exchange. They seem to agree with Karl Polanyi's diagnosis of the need to re-embed the economic sphere into social relations to protect society from the destructive impact of free-market forces. Just like the cooperatives that emerged in Europe in the industrial age, the new cooperatives can be viewed as a countermovement (another Polanyian term), or the self-protection of society from the market. Therefore, the role of this paper is to understand differences in internal structure of the "old" (pre-1939) and "new" (formed after 2010) cooperatives in Polanyian terms, and thus to reflect on two ways of forming a countermovement. I do this by examining the "forms of economic integration" identified by Polanyi - namely, reciprocity and redistribution - both in the "old" and in the "new" cooperatives.

This paper is based on fieldwork conducted in fourteen Polish consumer cooperatives between 2012 and 2015, as well as on archival research on Spotem and the prewar Polish cooperative movement (conducted 2015-2017).

The fieldwork comprises forty-three in-depth interviews with members of cooperatives from Warsaw, Kraków, Gdańsk, Łódź, Białystok, Poznań, Opole, Katowice and Wrocław. In 2015, I also conducted, together with Ruta Śpiewak, twenty semi-structured interviews with farmers who delivered to cooperatives from Warsaw and Kraków. I also examined written data, for example, from the websites of cooperatives and newspaper articles.

The archival research comprised an analysis of different materials produced by Spotem: articles in periodicals issued by the Union (mainly the Spotem monthly and Spólnota, a popular magazine issued fortnightly), books, office documents, letters as well as the memoirs of Spotem leaders, other Spotem employees and members of cooperatives belonging to the pre-war union.

\footnotetext{
2 The name of the organisation changed over time. At the time of its establishment in 1911 it bore the name "Warsaw Union of Consumer Associations". The full name mentioned in the text was introduced in 1935. The Union was commonly referred to simply as Spotem or the Spotem Union (Zwiqzek Spolem).
} 


\section{The cooperative movement in a Polanyian framework}

The birth of consumer cooperatives is symbolically marked by the establishment of the Rochdale Society of Equitable Pioneers in 1844, traditionally acknowledged as the first proper consumer cooperative (Holyoake 1908; Webb 1930). The original impulse came from socialist thinkers and social activists later referred to as "utopian", in particular Robert Owen, whose first radical social experiments based on cooperation were either paternalistic and hard to reproduce, or totally unsuccessful (such as the American New Harmony Commune; see Carmony and Elliott 1980). Yet the idea, when taken up by working-class leaders and adjusted to their everyday needs, proved its practicability. Consumer cooperatives proper were inspired by a variety of currents in the workers' movements of the time: Owenist, guild socialist and Christian socialist (Webb 1930; Fairbairn 1994). The Pioneers created a core set of principles guiding cooperatives that would later come to be known as the Rochdale Principles. The most significant of these were open membership, democratic control, a limitation on member compensation, autonomy and independence, and a focus on education (Fairbairn 1994). The general idea behind the cooperative movement was to counter economic exploitation by regaining control over consumption through the establishment of democratically governed enterprises run by their members. After taking control of the exchange process and eliminating private trade, the cooperatives were then to take over production (see Gide 1922). Although this far-reaching aim was never realised, cooperatives all over Europe had various degrees of success: they owned bakeries, foodprocessing factories and even facilities in other branches of industry. In many places, they had a considerable impact on lowering prices and raising the standard of living of working people, by providing them also with education and cultural activities. Cooperatives enabled ordinary workers not only to raise their standard of living, they also allowed them to rediscover their agency and create more humanised spaces in a world governed by impersonal market forces. Along with political parties and movements, consumer cooperatives were an important sphere of resistance to the new order.

It is this resistance to market forces that attracted the attention of Karl Polanyi, a philosopher, lawyer and anthropologist born in Budapest in 1886. During his studies, he joined counter-cultural and left-wing circles in Budapest (among others, the Galileo circle). After the first world war, he experienced the "golden years" of socialism in Vienna and was heavily influenced by workers' communal activities in the city. In 1933, he was forced to move to Britain after the rise of the National Socialist regime. There, he got involved, among other things, in educational activities in workers' circles (for and extended biography of Polanyi see Dale 2016). His main work, The Great Transformation, which he finished in the US 
close to the end of the Second World War, is devoted to examining how the liberal market order was imposed on European societies, which provoked social resistance. used to impose the liberal market order on society and the ensuing social resistance.

While Polanyi rarely refers to the consumer cooperative movement as such in his writings, the streams of pre-Marxist socialist thought in which he took an interest during his Viennese and British years (see Dale 2013, 61; 2016, 18-32) - Christian socialism, guild socialism and the Owenist movement, among others - were the same streams that inspired cooperativist thought. Likewise, the social movements that contributed to the growth of the cooperative idea were also at the core of Polanyi's interests in his later period. In The Great Transformation, he devoted a large amount of attention notably to the Owenist movement, which fostered different forms of economic institution (for example, the Villages of Cooperation). As Polanyi put it, "The consumers' cooperatives of Great Britain, which found imitators all over the world, were, of course, the main practical offshoot of Owenism". He concluded: "That its impetus was lost, or - rather - was maintained only on the peripheral sphere of the consumers' movement - was the greatest single defeat of spiritual forces in the history of industrial England" (Polanyi 2001, 178).

The starting point for my approach to cooperatives is the Polanyian concept of embedded economy, understood in opposition to market domination over other social institutions. According to Polanyi, the free-market economy is most fully exemplified by nineteenth-century Britain, where laissez-faire policies utterly transformed the human environment in an attempt to subordinate society to the rule of a separate economy, creating free markets for labour, land and money (1968a, 67-8). Following Polanyi's essay Aristotle Discovers the Economy (1968a, 82), I work on the premise that "the development from embedded to disembedded economies is a matter of degree. Nevertheless, the distinction is fundamental to the understanding of modern society." However, I also acknowledge that fully embedded and disembedded economies should be treated as ideal types (Hann and Hart 2011b, 9), since Polanyi was aware both of the fact that markets were present in pre-modern societies and that a fully disembedded economy would lead to the virtual destruction of society and nature. Even in the fervour of the Industrial Revolution, the economy was not entirely separate from society.

However, following Beckert (2009) as well as Dale (2013, 202), I reject Fred Block's idea (and similar interpretations) that Polanyi changed his understanding of embeddedness in his later writings to the concept of the "always embedded" economy (see Block 2003; Block and Somers 2014). In contrast to market-dominated societies, an embedded economy, according to Polanyi, rests mainly on other forms (mechanisms) of economic integration "the economic prerequisite for community", as Dale $(2016,52)$ puts it. These are reciprocity and redistribution (Polanyi 1977, 35-43). Market exchange is also seen as one of these forms 
of integration (as is householding), but is not dominant in an embedded economy. This changes with the laissez-faire economic model, which Polanyi perceives to be a result of grounding economic policy in the "liberal creed", a set of economic ideas that had been dominant in England since the 1830s (Polanyi 2001, 143). Polanyi considered them utopian; the liberal creed, or "dogma", as he wrote in The Great Transformation, "evolved into a veritable faith in man's secular salvation through a self-regulating market" $(2001,141)$. The disruption caused by liberating trade and the labour market could not entirely succeed: it released mechanisms of social protection in the form of countermovements (Polanyi 2001, 136-140).

Consumer cooperatives, in their classic form based on the Rochdale Principles, can be treated as a part of a countermovement in a Polanyian sense, that is, as the selfprotection of society from market forces. Countermovements materialised in a wide range of social activities: in demands for state intervention by different social classes (Dale 2013, 6061), but also in the many forms of society's self-organisation. By organising direct exchange between producers and consumers to the benefit of both (offering the producer a fair price and distributing surplus funds among members), cooperatives tried to protect both groups from the negative outcomes of creating fictitious commodities: land, labour and money. ${ }^{3}$ Consumer cooperatives not only provided working-class households with affordable quality goods, but offered them communal, cultural and intellectual possibilities (for example, lectures, Cooperative Day Celebrations, reading rooms, popular houses), creating a sense of belonging and community. This dual nature of consumer cooperatives is in keeping with a characteristic that Polanyi attributed to the nineteenth-century social experiments of the Owenist movement - their emphasis on the "appreciation of man as a whole" (Polanyi 2001, 176), as they were supposed to not only emancipate the people from their miserable material conditions but also fill in "the cultural void" that the working class found itself in during the rise of the industrial and free-market order (ibid., 166).

While many interpretations of Polanyi's concepts concern themselves with the macro-level (see Block and Somers 2014), I turn to those currents in Polanyian analysis that concentrate on tracing embeddedness "on the ground" in grassroots social initiatives (see e.g. Alexander 2011). Contemporary cooperatives, in Poland as well as in Western countries, differ in many ways from the old Rochdale model created in the nineteenth century. They should be regarded as a part of larger social movements that focus on everyday alternative modes of "practicing democracy" and new forms of organisation, something that, according to David Graeber, should be understood as these movements' very "ideology" (Graeber 2002, 9). The new consumer cooperatives, although operating in the very limited space of a few Polish cities, show clear connections to these movements in terms of both their form and,

\footnotetext{
3 Polanyi argues that land, labour and money are treated in the market system as commodities although they were not meant to be for sale (Polanyi 2001, 71-80).
} 
as Graeber suggests, their ideas (non-hierarchical structure, consensus decision-making). While I am aware of the limitations of my study and its immersion in the domestic Polish context, I also see it as a modest contribution to investigating the question of whether more globalised, interconnected movements that directly contest market fundamentalism (Hann and Hart 2011b, 9) can be regarded as a successful form of contemporary countermovement; that is, successful in the sense that they are able to mobilise a significant section of society against the destructive effect of the market.

\section{Społem: the Polish consumer cooperative legacy}

The first Polish consumer cooperative was established in Warsaw, then part of Russianoccupied Poland, in 1864. Only after the 1905 revolution, which resulted in the loosening of the tsarist regulations concerning associations, were consumer cooperatives able to develop on a larger scale in this part of the country (Chyra-Rolicz 1985). Soon they were supported by the Cooperative Society (Towarzystwo Kooperatystów), founded in 1906 by members of the progressive intelligentsia. The best-known founder of the Society and a pioneering theoretician of the movement, Edward Abramowski, had also been a cofounder of the Polish Socialist Party (PPS) in 1892, but soon decided to leave partisan politics, mainly due to his strong opposition to the idea of "state socialism" (see Abramowski 2013). Another founder of the Cooperative Society was Stanisław Wojciechowski, likewise a cofounder of the PPS (he left in 1905) and president of the Second Polish Republic between 1922 and 1926. After Piłsudski's coup d'état, Wojciechowski resigned and pursued a career as a scholar, becoming one of the leaders of the left-wing peasant movement. Abramowski's influential ideas on cooperativism were crucial for the development of a distinct ideology of consumer cooperatives, although he was also regarded by some as a romantic idealist whose thinking had to be counterbalanced by the more down-to-earth approach of leaders experienced in trade and in the practical aspects of operating cooperatives in a market-dominated reality (Giełżyński 1986).

Abramowski emphasised the ethical dimension of cooperatives. Forming consumer associations was a way for both individuals and the nation to rediscover agency. Cooperatives were supposed to be able create a "new man" who was "a free creator of life" potentially able to build real democracy in the advent of political freedom (Abramowski 2010, 166-173). This was crucial in the context of the Russian partition - the place of his birth and of his illegal political activity before emigration - wherein the tsarist administration tried to repress all forms of Polish civic engagement and self-organisation (although it never fully 
succeeded in doing so). Through cooperatives they could rise to form a new society, emancipating working people from the chains of capitalism but also from the impositions of state. Abramowski expected that cooperatives would supersede important social institutions to form an aggregate that he called stateless socialism (Abramowski 2010, 2013). Firmly believing in the role of self-help and brotherhood, he initiated friendship associations and ethical circles to encourage the development of these virtues in practice. In fact, Abramowski's emphasis on the role of individual virtues in cooperatives resonates with Polanyi's individualism and his stress on the ethical dimension of social action (see Hann 1992; Dale 2016, 19-21). The two thinkers also shared a basic appreciation of Christian ethics understood as a background for socialism.

The consumer cooperatives, which emerged in the harsh conditions of tsarist rule, each formed in different social milieus and were influenced by several political strands (including liberal or Christian democratic). However, they soon began to unite under the name of Spotem, a union of cooperatives founded in 1911 that provided education, practical tutorials and assistance in securing supply (the union's wholesale centre was established in Warsaw in 1911). After Poland's independence, Spotem united under its banner cooperatives dispersed all over the country. It also launched its own factories and mills, producing chocolate, sweets, cosmetic items, cigarette papers and more. In the interwar period, the union would also establish the Spotem bank, providing loans to consumer cooperatives in accordance with cooperative rules.

In 1925, after many heated debates, Spotem united with a rival cooperative union that had a much more direct political stance, the Union of Workers' Cooperative Associations (Związek Robotniczych Stowarzyszeń Spółdzielczych), formed in 1919. These two conflicting currents were labelled, respectively, "neutralist" and "class" cooperatives (two terms used in the cooperative press during the numerous disputes between members of each camp). Spotem demonstrated a strong anti-capitalist stance and positioned itself on the side of ludrie pracy (working people). But it followed the Rochdale principle of political neutrality and adhered to the vision of gradually changing the economic system from within to build a "cooperative republic", a concept propagated in Poland by Abramowski and inspired by Charles Gide, a classic French thinker of cooperativism and an early movement leader (see Gide 1922). ${ }^{4}$

Numerous polemics were held in the cooperative press regarding the relationship between "socialism" and "cooperation". Marian Rapacki, long-time head of the Spolem board of directors, argued in the spirit of Abramowski that, although both socialist and cooperative

\footnotetext{
${ }^{4}$ It has to be mentioned that Spotem's leaders gradually abandoned the concept of a cooperative republic, considering it utopian, especially after the 1929 economic crisis. They did not change, however, their view of the role of cooperatives in society and their politically neutral stance (see Bilewicz 2017).
} 
movements aimed for social ownership of the means of production, the cooperative movement opposed "state socialism" because the latter was based, in his view, on "mandatory state organisation" and "implied social change from above" (Rapacki 1923, 507), while cooperation rests on collectivities formed by free individuals that gradually contribute to the peaceful building of the "cooperative republic". Rapacki also claimed that cooperativism is a distinct way of fighting capitalism that should remain independent from political parties or trade unions - the latter pursue "class struggle", while cooperativism creates relations between producer and consumer that are essentially non-capitalist (Rapacki 1923). Cooperatives, as the socialist activist Bronisław Siwik (1923) argued in a similar vein, should constitute a much wider movement than political parties or trade unions. While revolutionary socialist politics has to rest on the use of violence, according to Siwik, cooperatives enabled the development of the "social spirit", a driving force of the socialist movement from below. For the Spotem "neutralists", it was the moral dimension of cooperatives - not just their purely economic function - that represented the core of the cooperative movement. In three articles that appeared in the journal Rzecapospolita spótdrielcza (The Cooperative Republic) issued by Spotem, the authors polemicised, indirectly, with the ideology of the rival "class" movement, which followed what was held to be the Marxist stance on cooperatives (Gide 1922, 40, 261-263). The "class" activists disavowed cooperatives as sidelining relations of production and, therefore, as withdrawing from class struggle. Through a Marxist lens, consumer cooperatives should be restricted to the working class and controlled by parties and trade unions, serving only as an auxiliary tool in the wider political struggle of the proletariat (Jossa 2005). The "class" cooperative movement in Poland was led by the Polish Socialist Party's left-radical faction and the Communist Party of Poland (made illegal in 1919, but it continued to exist unofficially). After unification of the two cooperative movements under the neutralist Spotem banner in 1925, the Communist Party dismissed the union and the "neutrals" as "bourgeois" or even "fascists" (Rusiński 1967).

In fact, the movement's independence and "neutrality" can be regarded as one of the sources of its relative success. At the time of reunification in 1925, Spotem already had 600,000 members (Mielczarski 2010), while in the 1930s around 10 per cent of the country's population participated in cooperatives of different kinds. While leaders complained that the Polish movement did not reach the scale that cooperatives had attained, for example, in Scandinavian countries, it was nevertheless celebrated as a huge success.

People in a variety of social classes joined cooperatives. The movement was born in the cities, as the largest cooperatives emerged in industrial areas among working-class circles. Cooperatives of state officials constituted a somewhat separate category, representing a more moderate, middle-class standpoint in the movement. In the late 1920s, more and more small cooperatives emerged in the countryside, and in the 1930s the majority of Spotem 
members belonged to such cooperatives. Indeed, most Spotem leaders were sympathetic to left-leaning peasant movements, and notably the youth movement Wici, which was fighting for land reform and social progress in the mostly poor and overpopulated villages. In various publications, cooperative activists emphasised the emancipatory role that the cooperative movement could play for the peasantry and called for solidarity between urban consumers and peasants. This aspect of the cooperative cause was especially emphasised by renowned writer Maria Dąbrowska (Dabbrowska 1939). Sympathy for the struggle of peasants, who constituted around seventy per cent of Poland's population, was one of the issues that distinguished Spotem from the mainstream of partisan socialist politics.

Statistics from the 1930s demonstrate the predominantly peasant and working-class character of the union. According to Dabrowska, 43 per cent of members of consumer cooperatives belonging to the union were peasants and 32.5 per cent were working class, with the rest labelled "other wage workers" (Dabrowska 1939, 28). The last group included many kinds of urban intelligentsia: not only state officials, but also clerks, teachers, and artists. An especially strong emphasis was put on strengthening the identification of members, who came from various backgrounds, with the movement: educational work took the form of organising very festive Cooperative Day Celebrations (from 1925), along with issuing flyers, posters, speeches, songs, poems, and so on, that were published, for example, in the popular magazine Spólnota (Community).

As archival documents show, consumer cooperatives varied in size and not all of them managed to be successful in the longer run. In the countryside and towns, cooperatives usually owned a small shop employing one assistant and consisted of a few dozen members. Consequently, the capital accumulation capacities of such cooperatives were limited and the board often consisted of people with little education or business experience. In the cities, the largest cooperatives had close to a hundred stores in different districts and hundreds or thousands of members. As in other European countries, cooperatives were run by a management body and a board of directors chosen by the members (in a majority voting system) during yearly meetings. The main role of an individual member was to stay loyal to her cooperative and refrain from buying elsewhere, even if a private merchant might offer lower prices. Both reciprocity and redistribution were present in cooperatives in the form of institutional arrangements. The cooperatives were reciprocal in the sense that all members had to pay a substantial entrance fee (share) upon joining. (This amount would be recouped over time if the member stayed loyal). Their loyalty to the cooperative made its very existence possible, especially in moments of crisis, which were all too frequent, particularly during the huge inflation crisis just after the establishment of the state (1919-1924) and during the 1929 economic crisis, which lasted until 1936 in Poland (Rusiński 1967). Redistribution played an equally meaningful role: in a classic Rochdale arrangement, cooperatives sold their 
goods at market prices, but the profit margin that would ordinarily go to the private merchant was divided between a common fund and a dividend that was usually repaid to members at the end of the year. Thus, cooperatives offered not only a sense of community, a strong belief in a common cause, but also the potential for substantial economic support for working families. Although the leaders of the movement emphasised its ideological aspects, it was mainly material interest that led members to join the cooperatives (which meant that many left when their cooperative went through difficult times). This was a serious problem that Spotem had to address. To maintain the integrity of the movement, it was necessary to spread the idealist cooperativist ethos. Extensive education about cooperatives was meant to raise awareness that the cooperative is, as one of the leaders of the movement, Stanislaw Thugutt, wrote, "not an ordinary store" (Thugutt 1934), but a part of a larger-scale project of social change requiring loyalty and commitment.

The Spotem union survived the Second World War under German surveillance reduced to only its economic function and banned from educational or cultural activities, with many such unions becoming centres of various forms of resistance (Jasiński 1965). After the war, with the advent of communist rule, some of the cooperatives were revived, but they could not regain their independence and democratic structure now that they were incorporated into a state-planned economy. Many new cooperatives were created from above, making membership in fact mandatory. No longer seriously in line with the Rochdale Principles, they were also no longer able to gain the social trust and recognition comparable to that enjoyed by the pre-war movement. Cooperative leaders who survived the war had to accommodate new regulations or leave the movement, as their activities were subject, as in all other economic sectors, to the party nomenklatura (Duszyk 2007). However, the cooperatives provided jobs, as well as the stability and predictability that were by no means certain after the economic transition around 1988-1992.

In this "shock therapy" period of rapid liberalisation imposed by the first democratic government (Kowalik 1991, Harvey 2009), the surviving cooperatives experienced a rapid decline, in part the result of hostile changes to legislation and a blackmail campaign in the media: they were portrayed as inefficient and invariably connected to the communist past (Brudziński 1999). One source of their bad reputation after the transformation was the fact that all forms of cooperatives had been bureaucratised and made subordinate to state structures during the era of the Polish People's Republic (1945-1989). Spótdrielnia (cooperative) had become practically synonymous with outdated, bureaucratised, nontransparent enterprises bound to perish in a new market order. Housing cooperatives gained an especially bad reputation and became a sort of symbol for this institutional arrangement more generally (Peisert 2009). Many of the existing Spotem cooperative retail chains were privatised, others became shady quasi-companies run in accordance with cooperative law 
only in theory. The phenomenon of "non-cooperative cooperatives" (private companies operating under the guise of cooperatives, such as quasi banks operating as cooperative credit unions) became common (Piechowski 1999). In this context of old cooperatives' losing credibility and of the normative chaos regarding the definition of a cooperative, it was all but impossible to seriously invoke cooperative values and principles.

\section{New cooperatives: revival of a tradition?}

Since the mid-2000s, we can observe a slow but gradual return of the idea of cooperativeness in the Polish public sphere. In 2006, the Parliament passed a law on social cooperatives, a specific kind of workers' cooperative designed to support "socially excluded" groups in finding employment; these cooperatives were based on the workfare framework of the new wave of social economy (Kazmierczak and Rymsza 2008). But renewed interest in the prewar cooperative tradition did not appear until the new consumer cooperatives began to form. Founders of these first emerging cooperatives referred especially to Edward Abramowski, whose cooperative writings were reissued the same year (2010) that the first consumer cooperative of this new type was established (see Abramowski 2010). These cooperatives claimed to be reviving the "authentic" notion of cooperation while establishing informal, independent and community-like entities capable of building direct links with farmers and creating, in Abramowski's terms, a "school of democracy and solidarity" again. The founders of the first cooperatives used a notion coined by Abramowski in his reissued 1906 essay Kooperatywa jako sprawa wyzwolenia ludu pracujacego ("The cooperative as a question of liberation of the working people") - the "communal fund" (fundusz gromadzk $i$ ) was used to name the surplus money added to the price of every product sold by the cooperative, the aim of which was to create a joint capital (Abramowski 2010, 64).

In fact, however, these new institutions that appealed to past and forgotten voices scarcely resembled the classic consumer cooperative of the pre-war period. The structure and design of these entities was almost wholly inspired by more recent influences. The first of the new cooperatives - established in 2010 and 2011 in Warsaw, Lódź and Gdańsk - were initiated and run for some time in large part by members of the Young Socialists Association (Stowarzyszenie Młodzi Socjaliści), an organisation founded in 2005 on the basis of

the former youth organisation of the Labour Union party (Unia Pracy). These first cooperatives were founded with a strong and peculiar anti-capitalist message - "we will 
abolish capitalism using this carrot" - as stated in a slogan on the website of the first Warsaw Consumer Cooperative.

The design of the cooperatives resembled food coops and other alternative organisations with roots in New Left traditions and later enhanced by anarchist currents in the alterglobalist movement (Day 2005): all put the emphasis on loose structure, an absence of formal hierarchy, the small scale, and consensus decision-making. This kind of new or alternative cooperative had already emerged in various Western European countries in the 1970s, experiencing a particular boom in Sweden and other Scandinavian countries, for example (Hettlage 1979; Stryjan 1994, 1996), as well as in the United States (Knupfer 2013). Another wave came after the 2008 economic crisis. Soon the notion of "new cooperativism" emerged, a notion that encompasses a range of cooperative initiatives characterised by their "grassroots" character and a strong anti-capitalist and often environmentalist stance (Vieta 2010). Without any stable governing bodies (except temporary "coordinating groups" set up for specific tasks), the work in most of those entities is handled by members in rotation. All important decisions are to be taken at meetings (usually monthly), typically by using the consensus method. With their strong emphasis on inner relations, "participation" and community, these new cooperatives tend to deliberately maintain their small-scale and informal character.

\begin{tabular}{|l|l|}
\hline \multicolumn{1}{|c|}{ The Społem cooperatives } & \multicolumn{1}{|c|}{ The "new" cooperatives } \\
\hline $\begin{array}{l}\text { Formal organisations, operating in } \\
\text { accordance with the law on cooperatives } \\
\text { passed by the Polish Sejm (lower house of } \\
\text { Parliament) in } 1921 \text { and registered with } \\
\text { local courts. }\end{array}$ & $\begin{array}{l}\text { Mostly informal collectives (a minority } \\
\text { formalised as associations). }\end{array}$ \\
\hline $\begin{array}{l}\text { Centred around a jointly owned store or } \\
\text { stores run by paid staff (shopkeeper/shop } \\
\text { manager). }\end{array}$ & $\begin{array}{l}\text { Goods distributed during "shopping } \\
\text { sessions" (every one or two weeks or } \\
\text { irregularly) often organised in temporary } \\
\text { spaces (an NGO, a café); a small minority } \\
\text { of cooperatives have stores. }\end{array}$ \\
\hline $\begin{array}{l}\text { Governed by a management (of 2-3 } \\
\text { people, including a president of the } \\
\text { cooperative) and a board of directors } \\
\text { chosen by all the members on yearly basis } \\
\text { (one member, one vote system). }\end{array}$ & $\begin{array}{l}\text { Deliberately "non-hierarchical"; initially all } \\
\text { functions performed on a rotational basis. } \\
\text { At a later stage, many cooperatives } \\
\text { established groups of coordinators chosen } \\
\text { by members. Decisions taken by consensus } \\
\text { during meetings (usually held monthly). } \\
\text { Some decisions taken by smaller "special }\end{array}$ \\
\hline
\end{tabular}




\begin{tabular}{|l|l|}
\hline & $\begin{array}{l}\text { task" groups; in reality cooperatives often } \\
\text { managed by the "most active", informal } \\
\text { leaders. }\end{array}$ \\
\hline $\begin{array}{l}\text { Conditions of membership: a substantial } \\
\text { entry fee (around one month's salary of a } \\
\text { labourer); dividend paid to all members at } \\
\text { the end of the year on the basis of the } \\
\text { value of their purchases; part of the profits } \\
\text { collected for a common fund. }\end{array}$ & $\begin{array}{l}\text { fund; in some cooperatives monthly } \\
\text { contributions are a condition of } \\
\text { membership; no individual dividend. }\end{array}$ \\
\hline $\begin{array}{l}\text { Duties of members: cooperative loyalty, } \\
\text { adherence to cooperative values. }\end{array}$ & $\begin{array}{l}\text { Participation in cooperative duties (on a } \\
\text { rotational basis) and social activities. }\end{array}$ \\
\hline
\end{tabular}

Table 1. Differences in structure and economy between Spolem cooperatives (before 1939) and the cooperatives that have emerged in Poland since 2010

The aim of consumer cooperatives is to get in contact with local farmers for the supply of high quality, preferably organic, food for their members. Initially, the new consumer cooperatives had no experience in contacting farmers, so members started by delivering produce that they bought at big wholesale centres on the outskirts of cities, where some individual farmers sell their produce. Eventually most of the cooperatives managed to establish relations with individual farmers, although not without difficulties. Some cooperatives established lasting ties with food producers, while others struggled to retain them, largely due to very small orders that meant delivery to the cities was simply not viable for the farmers. Our initial research among farmers working with cooperatives has shown that most of them are not traditional small farmers, but have made a conscious decision to establish "alternative" farms that follow ecological natural farming models. Most of these farmers have also a university degree and either grew up in an urban setting ("back-to-thelanders") or returned to their family's land after studying and working in large cities (see Bilewicz \& Śpiewak 2015). The reason that traditional farmers rarely deliver to cooperatives is probably because of their lack of social capital, more of which would enable information and direct links to urban consumer movements: most farmers are simply unaware of the existence of such groups or they find them too small and ephemeral to be worth cooperating with.

Although today's cooperatives are seemingly based on the same basic principle as entities from the past (forming an organised group of consumers to eliminate middlemen and trade directly with producers) as well as (at least in the first cooperatives founded by 
social activists ${ }^{5}$ ) the same broader, long-term goals (countering the capitalist mode of exchange and ultimately production), the organisational shape of the new cooperatives is very different from their precursors. Supposed commonalities with the "old" cooperatives, as suggested by references to Abramowski or the pre-war consumer-cooperative movement in general, are in fact misleading, as the new cooperatives were formed with a social background that differs significantly from that of the "old" movement. Furthermore, due to their structure, they are often unable to provide economic stability or perform their necessary functions sustainably and fluidly. Some also fail as communities, which invites consideration of the non-purely structural factors potentially at play. The structural differences between the past and present cooperatives are presented in Table 1.

\section{How re-embedding food exchange does (not) work in cooperatives}

\section{Reciprocity and redistribution}

There are several reasons as to why the re-embedding process in cooperatives is, in my view, at best fragmented and slow, and that the very structure of the majority of cooperatives should be considered a constraint. In fact, as I will try to demonstrate, for these communities, food provision is sometimes only a marginal goal, a fact that is accepted by a substantial part of the membership, who treat cooperatives mainly as facilitators of networking or as a circle of like-minded friends, and don't expect to purchase most of their daily food through it.

\section{A fragile community: the problem with reciprocity}

According to Hettne $(1990,2006)$ and other authors who interpret Polanyi within the socalled new regionalism paradigm, in the era of neoliberalism the re-embedding process is likely to happen in small, decentralised communities and be based predominantly on the principle of reciprocity. While redistribution is most typically attributed to the state or another social institution with a centralised governing body, the movements of reciprocity are "symmetrical, their locus being the community" (Dale 2013, 117).

\footnotetext{
${ }^{5}$ It must be emphasised that the anti-capitalist stance does not pertain to the other type of new consumer cooperatives, which I refer to below as "consumption-oriented" (see page 21). However, they are not the main focus of this paper (for detailed information on this type of cooperative, see Bilewicz and Śpiewak 2015).
} 
While in my opinion it is in general doubtful whether reciprocity alone could ensure a successful re-embedding of the economy, it is also necessary to look at potential constraints to reciprocity in any given social structure. Many of the cooperatives are highly fragile entities that experience recurring crises and may be disbanded temporarily or permanently as a result. My interviews and observations suggest that these crises are caused by the lack of volunteers to perform essential duties (insufficient commitment of members), a huge member turnover and insufficient coordination of work. These factors actually endanger the continued existence of reciprocity in cooperatives. The first factor - the passivity of the majority of members - often gets invoked by the most active members, mostly the founders of cooperatives, who complain about having to do all the work on their own. The majority of members, in the reports from the "activists" or factual leaders, do not really participate in cooperative activities, instead treating the cooperative as an "ordinary store". This expression recalls Thugutt's observations and suggests that it is a problem also that the movement has historically encountered. ${ }^{6}$ It came up in many of my conversations with cooperative members. One of the founders of the cooperative in Gdańsk and a former leader of the Young Socialists Movement said to me:

\begin{abstract}
Unfortunately, many cooperative members treat it as a slightly better, cheaper and healthier food store, at least half of them, the same half that buys ecological products. Yes, a cheaper, a slightly cooler ecological food store. They come or send some of their friends, they select their purchases, and this is how their participation in a cooperative looks. We find it lamentable, since the cooperative, by definition, should be democratically governed by us all, and every member of a cooperative has one voice that is equal to all the others.?
\end{abstract}

During the second nationwide Consumer Cooperative Rally, organised in Eódź in 2013, a discussion on "participation" was held in which members from different cooperatives from all over Poland tried to find a solution to this problem. Their diagnosis was pretty similar:

${ }^{6}$ It is important to remark, however, that this affinity is somewhat superficial, as commitment meant something else in the former cooperatives, where everyday duties were usually performed by paid staff or board members. A member's duty was regarded not as participation in the everyday tasks, but as faithfulness to one's cooperative store against all odds as well as spreading the ethics of cooperation.

${ }^{7}$ All translations of quotes used in the article are mine. 
I think that we still understand the cooperative in a simplified way. For a cooperative is not just a store where you buy healthy food from a farmer. The cooperative is cooperation in a group, it is social cooperation.

The passivity of the majority results in a situation in which all work and virtually all cooperative affairs are in the hands of the few most committed activists. These people sometimes consider themselves "idealists" or "freaks" deeply convinced by the ideology behind the cooperatives. As Marcin ${ }^{8}$ of the Gdańsk Cooperative recalled, he had to "see to everything": he set the date of the shopping sessions and informed the group, opened and closed the Social Centre where the cooperative was located, and made sure that the people expected to take shifts for weighing, packing produce and cleaning up had shown up. He often also delivered produce from farmers and carried out other "functions" meant to be performed by all members on a rotational basis.

I went often [to fetch produce], it was often the case that no one wanted to do it, so I said - okay, I'll go, so that the shopping session can take place anyway. I've had enough of that. So recently there was simply no shopping.

Marcin tried to distribute some responsibilities among other members, but was not always successful. He also admitted that his disproportionate involvement in cooperative matters gave more power to him than to the others, as he and a few other active members made de facto decisions on matters that were meant to be discussed collectively. Sometimes the daily management of cooperative affairs required some sort of sacrifice. Maciej, another active member of the Gdańsk cooperative, a person with irregular work and very modest earnings, took part in the cooperative labour, often volunteering to go early in the morning to the wholesale centre to buy food from farmers, even when he couldn't afford food from the cooperative himself. He said it was his contribution to the cooperative when he was unable to "support it financially" by taking part in shopping. The Gdańsk cooperative collapsed in 2014, around a year after my visit.

A similar situation occurred in the Lódź cooperative, as recounted by Piotr, once one of its leading activists:

8 The names of the cooperative members have been changed. 
It was a major problem connected with participation and the fact that I took on too many of the obligations, and that we had not enough people to work. At some point I felt burnt out, I wasn't able to keep going like that and the cooperative had to be suspended for a month.

Indeed, the Lódź cooperative, which for some time was one of the most successful with around two hundred members, has had more than one period of inactivity due to both a lack of member participation and to internal conflict. The cooperative was relaunched, but Piotr no longer participates as a member. Brief terms of membership, even among the most committed and active members, is a typical situation in most cooperatives. The Warsaw Consumer Cooperative had to operate with high turnover and a constant influx of new members who had to learn the rules and get acquainted with co-members and coworkers. Most members stay no more than a year, sometimes even only a couple of months.

Some activists have faulted other members, i.e., the inactive majority, for not having enough awareness of cooperative values and principles and not being "political" enough. For them, as for Piotr, the cooperative is mostly about politics:

It is political that we cooperate in a just way with our deliverers; it is political that we buy locally and seasonally, because it is totally political. We can buy a potato at the Lidl discount supermarket, which is transported over hundreds, even thousands of kilometres from Israel, or we can buy a nice ecological potato coming from a distance of forty kilometres. That's a huge difference, our money makes that difference $[\ldots]$.

Therefore, it is the "normal" people (those who are not politically aware, in the terms used by some of my interviewees) who have embraced the cooperative as a "chic store" providing them with cheaper ecological foods and who fail to understand what a democratic collective enterprise is all about. While this might be true in part, I would suggest instead that the design of the institution itself does not produce a basis for the stable relations necessary for reciprocity. Most work of the cooperatives is done via the Internet, where many discussions on common issues also take place. The rotational working arrangement does not enable people to regularly meet on the same "shift" and develop closer relationships as well as common "workshop rituals" that can facilitate stable cooperation (Sennett 2012). Although most cooperatives strive to integrate their members (organising picnics, communal cooking, discussions or workshops), they fail to retain them for a long period of time. The non-hierarchical structure, intended to avoid the alienation of the "petrified 
bureaucracy" of older cooperatives and enterprises, whether socialist or western ones, has produced its own alienation: chaos, instability and sometimes a surprising degree of anonymity in a small group meant to form a community, a "small society" (one member said of the cooperative: "it is a small society, a base of a society. It had to look like this in the beginning").

Is there, however, more that can be learned from the passivity of the majority of cooperative members? According to Polanyi, reciprocity requires a "supporting structure" in the form of "symmetry", described as a sort of tribal subdivision involving individuals building partnerships or relations between villages or moieties $(1977 ; 2001,51)$. While it is important to remember that Polanyi is referring to pre-modern arrangements, long-term reciprocity in the new cooperatives still seems to need a personal and stable form of relationship based on more than just the types of friendship - or rather acquaintanceship that develop through involvement in the cooperatives. ${ }^{9}$ In pre-war cooperatives, reciprocity was ensured by what was called "cooperative loyalty", which was, in turn, strengthened by propaganda and moral education. Spotem leaders took this very seriously - solidarity was a "duty", according to a text by Charles Gide translated and printed in a 1906 edition of Spotem magazine. This moral dimension, taking the form of a duty or obligation, is absent or rare in present-day cooperatives: for the most committed activists, what matters is being on the right political path or on the ethical side of consumption. For most members, selffulfilment and a desire to take part in something "alternative" or "non-conventional" motivates their participation. Indeed, as Marcin pointed out, cooperative activities for some resemble "play":

In general, the cooperative is a sort of a $[\ldots]$ nice way to have some fun $[\ldots]$ you can't rely on it in terms of your nourishment, you can't treat it as your only food supply, because shopping sessions are rare, most of the people have to commute quite far, and, somehow [...] to go and collect your shopping is anyway a sort of [...] effort in relation to what you get, because what you get is of [...] highly variable quality. Most of the wholesale centre things are the very same things that can be bought at the market.

\footnotetext{
9 This aspect of Polanyi's thought is in fact problematic, as it is not entirely clear how we should apply the categories derived from studying ancient or tribal communities to the modern context. This ambiguity led to the split (now resolved) among economic anthropologists between "formalists" and "substantivists" (see Hann and Hart 2011a, 56-97). I would argue that the forms of integration are still applicable to the contemporary societies, although Polanyi himself was quite unclear about how to understand them in the contemporary context. His support for the Soviet Union (Dale 2016, 80-94), even during Stalinism, leads to further confusion, since his general style of argument, e.g., focusing on exchange and distribution rather than production, his view of class conflict and the Christian and individualist motifs of his thought seem hard to reconcile with communist ideas and practice.
} 
The weak and chaotic structure of many cooperatives prevents them from becoming a stable source of quality food, and there is no other strong motivation that would bind people to them for a longer period of time. In many cases, the cooperatives also cannot offer a stable source of income for farmers. Without some sort of a Maussian "obligation to give", reciprocity in cooperatives does not seem to have good prospects. What happens in cooperatives, however, seems to be in accordance with the general spirit of the new social movements developing in the West since the 1960s: their ephemeral structure is a reflection of a general emphasis on self-realisation and individual goals that underlie collective action (Melucci 1989; Rose 1997). This is confirmed in a recent study that analyses people's motivations for participating in recently developing informal movements (including cooperatives) in Poland (Górniak 2014). This larger framework means that people enter a cooperative then leave it readily when something more attractive is offered.

\section{"Where is our wallet?" Impaired redistribution}

Redistribution was one of the most important functions of classic consumer cooperatives based on the Rochdale Principles. By establishing a direct link to producers and at the same time selling at market prices, cooperatives made it possible to shift a profit that would otherwise fall into private hands to the community of members and have it partly returned to them as a dividend. As Stanisław Thugutt wrote, the aim of the cooperative was not profit, but "protecting its members from exploitation and generat[ing] savings for them" (Thugutt $1934,4)$. It was thus meant to be a Polanyian countermovement against market forces. After covering the necessary expenses connected with running the shop, the remaining surplus money was to be redistributed among members according to the value of their expenses in the cooperative (but irrespective of their initial shares). Some of the surplus was democratically allocated through a common fund (this could be used for the cooperative enterprise or cultural or educational facilities for members).

As mentioned above, in most new consumer cooperatives, redistribution took the form of a fundusz gromadzki (communal fund), established by adding 10 per cent to the producer's price of each product. However, the fund's value has turned out to be largely symbolic in most cooperatives. Due to the small numbers of members and the often irregular "shopping sessions", no considerable surplus can develop. In the Warsaw Consumer Cooperative, it oscillated from several hundred złotys up to two or three thousand (eighty to twelve hundred euros) in the cooperative's best months. This covered the costs of purchasing basic supplies for the cooperative's storage room (shop scale, shelves, food boxes, etc.) and 
organising meetings, but not much more. Moreover, due to general chaos in the cooperative, it was difficult to accumulate the money for the fund. The simple reason for that was that it was held in a communal wallet that passed between the people who happened to perform the function of "shopping coordinator" in any given week. In 2012, the wallet disappeared, with all the cooperative's savings. The person who lost or stole it was never found, as no one bothered to launch an investigation. This caused many disappointed members to leave the Warsaw cooperative.

The initial aim of the fund, apart from covering necessary costs, was to support members in times of need (covering unexpected health care costs, for example). This, however, did not work and not just because of the fund's paucity. Julia, a Lódź cooperative member, complained about flaws in the way the communal fund works:

\begin{abstract}
I know that there are people in the cooperative who can't buy a larger amount of food in a given moment, or almost nothing. And they will never ask for help. Even very active people. And I think there is a barrier on their side. And it is psychological. And there is the question of how to avoid this barrier. For me, more formalisation and more anonymity in asking for help would be a solution. In the state of total informality that we have here, a person has to talk about his problem at a meeting, say that he simply does not earn much or is without a job, I think it is a big problem.
\end{abstract}

In the "old" cooperatives redistribution was institutionalised as a more impersonal mechanism - the dividend was paid at the end of the year according to the value of a member's purchases, which was filled in on special sheets. The personal and informal character of the present-day cooperative meetings actually makes this more difficult to implement. Most of the cooperatives that introduced the communal fund very quickly simply ceased to use it that way. The call to formalise this process seems very reasonable, as Polanyi reminds us that redistribution requires another supporting structure based on "centricity", which is "present to some extent in all human groups, provides a track for the collection, storage and redistribution of goods and services"; it must also result in an effective division of labour, as the economic system is a "mere function of social organization" (Polanyi 2001, $52)$.

As we see, the organisation of most cooperatives makes redistribution almost impossible. Storing money is difficult due to lack of stability in positions requiring responsibility. Storing other goods is also challenging in the long term, as most of the cooperatives, unable to rent their own space, must rely on NGOs, state-cultural institutions or informal organisations (such as squats) to grant them temporary space for free. 
The cooperatives often change their location, which makes it hard to build permanent infrastructure.

Along with the absence of a fixed space, the programmatic lack of central authority (the "non-hierarchical" character of the cooperatives) seems to be a key factor in their general inefficiency and the feebleness of the redistribution process. Cooperatives base themselves on a conviction, popular among different streams of the "newest social movements" (Day 2005), especially those with anarchist inspirations, that a new and more just social order should eliminate all hierarchy and ultimately all power. Thus, in the beginning, no provisions were made for creating reasonably permanent management or administrative roles. Later, many cooperatives introduced some reforms, e.g. the Warsaw Consumer Cooperative established a "coordination group" that was supposed to be chosen again every three months. However, this has not resulted in anything lasting or stable, since the extent of the coordination group's power was not precisely defined and most members did not appear to be very committed: presumably due to its lack of genuine answerability to the collective, which did not possess any tools to dismiss the coordinating group. Many members complained about chaos, inefficiency and prioritisation of the cooperative's convivial function above its provisioning tasks. Such formation of informal hierarchies and elites in informal structures has been described in a classic essay by feminist activist Jo Freeman (1971) as the "tyranny of structurelessness". She notes the ineffective character of such groups in dealing with complicated issues, as well as the emergence of informal elites and "stars" who dominate it. Such matters were also invoked by my informants, who spoke of "people with stronger personalities" and "rhetorical talents" dominating the group. "The force of the arguments" does not count, according to one of them.

In most cooperatives all matters are decided at meetings based on the principle of consensus (Bressen 2007). A typical feature of many "alternative" organisations in the west, this principle has proven quite problematic (Sennett 2012), and most Polish cooperatives fully confirm this. Warsaw Consumer Cooperative meetings often lasted several hours, with lengthy discussions on minor issues. A feeling of emptiness and infertility prevailed in those discussions. Adam, a former Warsaw Consumer Cooperative member, recalled:

Consensus decision-making is $[. .$.$] very attractive in a way [\ldots]$ on an ideological level, but hard to use in practice. It turns out that we can't make any decision [...], or finally, after many hours of discussion, we make some insignificant decision that does not really change much. We make this decision in a small group of people, because other people were somehow excluded from the decision-making process: they could not make it to the end of the meeting, or they let themselves be convinced because they were tired, or the pressure was so hard that they gave up. That is how I see it. 
These long and exhausting meetings were another reason many members became disillusioned and left the cooperative or became completely passive. Almost all of the most committed members - namely, those for whom the cooperative actually formed a close circle of friends and was an important part of their lifestyle - have left.

\section{Possible solutions: informal and formal}

It would be inaccurate to state that all Polish consumer cooperatives are in a state of stagnation or collapse such as that experienced by the cooperatives I described above. There are two basic types of cooperatives that transcend the initial model: the first type is what I term consumption-oriented cooperatives (see Bilewicz and Potkanska 2013; Bilewicz and Śpiewak 2015), informal Internet networks that actually partly resemble shopping groups; the second is represented to date by just one cooperative, the Warsaw Dobrze, which is registered as a formal association and has established a shop. These cooperatives have introduced very different, even mutually exclusive institutional arrangements that, however, enabled each of them to cope to some extent with the problem of disorganisation and insufficient member commitment.

Consumption-oriented cooperatives are usually not oriented toward democratic decision-making; they mostly have centralised power structures in the form of so-called group administrators (usually two or three persons) who coordinate the necessary activities and make the most important decisions. Most of the work is done through the Internet, with individual members being responsible for "actions" for produce from a particular farmer or producer. Consumption-oriented cooperatives are able to have more members (sometimes a few hundred), and they meet weekly to redistribute the products, which they sometimes collect directly by car from farmers or small processing units (most farmers come to the city to deliver the goods). Lack of member commitment does not cause larger structural problems for these cooperatives - the administrators simply remove inactive members from the Internet group. This enables enduring reciprocity, but at the price of a kind of "despotic" power on the part of the administrators and the absence of the democracy that is crucial for cooperatives. Although in some cooperatives, as in the Kooperatywa Grochowska in Warsaw, this has changed after they adopted Rochdale Principles. Significantly, these entities have considerable purchasing power, thus enabling them to make large orders from farmers, 
providing them considerable profit; they offer also high prices for sophisticated goods of exceptional quality. ${ }^{10}$

In contrast, the Dobrze cooperative, established in 2014, is formalised as an association and has opened two stores in Warsaw (the second one was launched in summer 2016). It is run partly by members who take rotating shifts and partly by paid staff. Formally, it continues to be "non-hierarchical", and adopts the principle of consensus for its monthly meetings. There is, however, a coordination group that includes the formal management of the association. An association as a legal form requires the preparation of yearly financial reports and the need to pay rent for the shops and wages of employees - such are some of the factors that motivate most members to participate actively in cooperative tasks and daily life. Along with its own members (over two hundred), the cooperative employs people as shop assistants and supply coordinators. Dobrze, inspired by the rules of the Park Slope Food Coop in New York City, has introduced one mandatory three-hour shift per month for members in the cooperative shop. This gives the cooperative a solid existence, but all this also has its cost: the produce, notably bought from niche ecological farms, is much more expensive than at most other cooperatives, not to mention ordinary stores. But this is not all; the financial flows in the cooperative in fact constitute the opposite of redistribution: along with the initial share, members pay monthly contributions (twenty-five złotys, about six euros) to the cooperative to cover all its costs. The cooperative, in this arrangement, no longer serves to "protect members from exploitation"; instead, it offers them a sense of community and access to regional and quality food in exchange for their free work and money. Somehow, strangely, embeddedness has itself become a sort of a commodity, and an exclusive one at that (some similar findings are in Winter 2003). Although in the classical Rochdale cooperatives the members were obliged to pay substantial initial shares, they later obtained dividends that made their membership, at least in most cases, a form of economic protection. In Dobrze, protection instead concerns the members' health and well-being (access to quality food), not their finances. It can be a solution for middle-class members, but obviously not for poorer people who cannot afford ecological and quality food, even at the lower prices offered by the cooperative.

These two solutions, put in Polanyian terms, have introduced two different kinds of centricity: the first in the authority of the administrator, the second in the formal framework of the association and stores that impose strict regulations on members. The stable character of the two cooperatives enables social relations to flourish (and to form certain kinds of "symmetries" in the group: in both cases, many joint activities are organised by members,

${ }^{10}$ It is important to remark that not all cooperatives that fall into the "consumer" category fit into this description. In the years following this study, some cooperatives from this group became more democratic and dispensed with Facebook for carrying out their daily operations. 
such as picnics, bartering used goods, common charity actions in the consumer-oriented cooperatives, and communal cooking and cultural/political events, the last mostly in the Dobrze cooperative). These two forms of cooperative, centralised through a person or institution, enable a stable exchange of food between producers and consumers and offer a rich social life to members. Reciprocity and redistribution are present in both cooperative models, at least to some extent, but not in an individual manner as in the classic Rochdale model. The funds of the members serve their common needs (as assets to run stores, to arrange a storage room or to organise a communal meal), but are not returned to members in the form of dividends.

\section{Cooperatives and class interest}

Who has access to the benefits offered by a community that forms such an "embedded island"? In the case of informal "activist" cooperatives and, to a larger extent, the Dobrze cooperative, the members are mainly young urban intelligentsia seeking a form of alternative lifestyle (Bilewicz and Potkanska 2013; Bilewicz and Spiewak 2015). Many of them have precarious jobs that do not provide high incomes but allow for a flexible schedule that enables them to participate in cooperative "shifts" (often during regular working hours), lengthy meetings held on workdays, and picnics and parties. The majority work in NGOs, at universities, at public cultural institutions, in the media or as freelancers; many are $\mathrm{PhD}$ students, mostly in the humanities and social sciences. Their self-definition as "freaks" living non-conventionally is contrasted with the figure of the "normal" (normals), a politically indifferent person outside the activist group or a potential member who needs to be drawn into the cooperative movement. The relationship between the "activists" and the "normals" is highly ambivalent: "normals" are seen as desirable and very welcome in cooperatives; simultaneously, when some of these "normals" join, they are partly blamed for cooperative inefficiency and accused of lacking proper political awareness.

The elitist character of the consumer cooperatives is reflected in the assortment of the products they offer. The emphasis, which has grown stronger in recent years, on buying organic food makes the produce sold actually more expensive than in ordinary supermarkets, something that runs counter to the goals of early cooperatives. Many of the cooperatives have decided to stay vegetarian and thus concentrate on selling specialty vegetarian and vegan foods (tofu, tempeh, chia seeds, etc.). Cooperative members deem food sold in supermarkets to be inedible, unhealthy and full of "chemicals", but the solution most cooperatives offer renders them even more exclusive. As Jack Goody argues in Cooking, Cuisine and Class (1982), 
the upper classes have distinguished themselves for centuries by eating foreign, exotic food, with the invention of baute cuisine being linked to the emergence of complex social stratification. In the contemporary food regime, "exotic" might be replaced, paradoxically, by terms including "local", "natural", "organic" and "vegetarian" (or "vegan"). The emergence of industrially mass-produced food, according to Goody, has contributed to making food manners more egalitarian. It seems notable that this argument was made just at the time of the birth of the Slow Food movement (Brunori 2007) and other alternative food movements that were soon embraced by a middle class inventing its "green distinctions" (Horton 2003). The alternative-food movements in fact engage in elitist consumption practices.

The intelligentsia in Poland, as in many other Eastern European countries, had a singular position in society. Some researchers claim that this class - or stratum, as there is no agreement about the class status of the intelligentsia (see Żarnowski 1964) - had a hegemonic position in Polish society since the second half of the nineteenth century that has lasted even through post-war socialist rule (Szelenyi 1982; Zarycki 2003, 2009). Most of the intelligentsia came from an impoverished gentry background: due to a lack of independent state structure in Poland and other factors undermining the formation of a bourgeoisie, the intelligentsia took a leadership position in the second half of the nineteenth century, when it was believed to be preserving national identity and values. However, intelligentsia leaders were also crucial in the formation of the socialist movement in Poland. The largest socialist party, the PPS, was led largely by intellectuals with backgrounds in the gentry and an assimilated Jewish intelligentsia. The pre-war cooperative movement, involving many former prominent PPS members, was also initiated and led by people with typical intelligentsia or even gentry or aristocratic backgrounds, as is reflected in the early articles published in the Warsaw journal Ekonomista in the second half of the nineteenth century by leaders of the Cooperative Society and Spotem. Most of the iconic pioneers and theoreticians of Spotem, including Abramowski and Wojciechowski, were born, somewhat paradoxically, in country mansions or into impoverished urban-intelligentsia families with gentry backgrounds. However, both PPS and Spotem were able, after some time, to gain broad social support and attract workers and, in the case of Spotem, wide peasant backing as well (some peasants also came to join its leadership).

I return to the history of cooperatives to provide a basis for my interpretation of Polanyi's argument about class interest and social change (2001, 158-71), which basically runs counter to the Marxist tradition. Because human interests are social before they are economic, Polanyi argues, successful countermovements involve cooperation between different social classes that are able to join forces despite sectional interests. It is in times of change that the entanglement of class interest with "the needs of society" (as a whole) and, consequently, with the fate of other classes, becomes visible $(2001,159)$. Those needs, 
Polanyi argues, are not predominantly economic. In the case of historical countermovements, he writes: "Almost invariably professional status, safety and security, the form of a man's life, the breadth of his existence, the stability of his environment were in question" (Polanyi 2001, 160).

In fact, according to Polanyi, a countermovement must involve class leadership, in which one class represents the whole of society struggling for self-protection. By joining or leading the protectionist movement, this class is not merely representing its own economic interests, since not only income, but also other basic needs, common to all classes, are threatened by the commodification of land, labour and money. Somehow, the (similarly elitist) leaders of the "old countermovements" in Poland were able to represent interests other than their own "sectional" class interests, enter into dialogue with the part of the society that they wanted to protect and to mobilise hundreds of thousands of people in support of their cause. This seems not to be the case for the new consumer cooperatives, at least not in their present shape. On their way to a "more democratic, ecological, and just economy", they fail to take a leadership position; they are enclosed in their own srodowisko, the informal social milieu that Janine Wedel has described as the essence of social life in Poland during the last decade of "real socialism" (Wedel 1986). The tendency to remain confined in small "intelligentsia ghettos", as described by sociologist Józef Chałasiński (1958) is, however, a phenomenon with deeper roots in Polish history, one that goes back to the creation of an urban stratum of impoverished gentry that heavily relied on informal personal ties. However, trying to understand this phenomenon by referring only to the history of local class relations may be misleading, since similar movements in Western Europe and America are also reported to have a predominantly middle-class or uppermiddle-class - and therefore also exclusive - character (see Goodman and Goodman 2009; Bryant and Goodman 2013).

\section{Conclusion}

As I have attempted to demonstrate, most of the new consumer cooperatives to date have failed to develop the requisite mechanisms for successful economic integration, namely reciprocity and redistribution. Although they offer an "alternative" to the usual shopping at supermarkets or other stores, providing access to ecological and healthy food in a personal, small-scale setting, few of them are stable enough to permit long-standing cooperation with farmers and a firm organisational structure. 
The re-embedding process in cooperatives seems to be only partial, as it delivers only a semblance of trust and personal relations, a highly uncertain promise of Gemeinschaft rather than a stable economic mechanism integrated into the social fabric of the cooperative and its environment. The exclusive character of most cooperatives (strongly based on lifestyle and special food habits) and their peculiar "structureless structure" makes them inaccessible to the majority. Thus, their countermovement potential is fairly weak - they are unable to mobilise an alliance of different classes.

It is possible, though, that this situation represents the initial stage of a larger movement, i.e. that some more stable and less exclusive structures will emerge in the future. The history of Polish cooperatives indeed began as feeble attempts by the intelligentsia to build cooperatives in the second half of the nineteenth century - something the Polish Marxist anthropologist Ludwik Krzywicki described as a failure due to their wrong social basis (Krzywicki 1903). The activity of the cooperative society that gave birth to Spotem enabled the growth of a movement that transcended class barriers. The two different routes to stability that have emerged among present cooperatives show possible paths for the future. The first path, however, acquires stability through installing a strong leader, reducing the democratic aspect of the cooperative, while the other does so through establishing a store and formalising as an association but at the same time retaining relatively high prices and monthly membership dues, thus building an economic and social barrier to participation.

The interests that the new cooperatives try to represent - access to healthy and natural foods, protection of small family farms and re-embedding food exchange in social relations - are basically common to all social classes. These interests - just as in Polanyi's analysis - are not primarily economic; they are social interests (1968b) connected to physical as well as psychological well-being, a sense of security and ties to the local community and nature. While remaining cautious about overly facile historical analogies, it seems plausible to suggest that in order to gain wider social support, cooperatives will have to return to the Rochdale Principles (such as individual members' participation in profits) and invent a "new neutrality" that could help transcend class barriers. This would probably entail moving beyond strict political positions (including not insisting on "non-hierarchical" and informal structures) and identities strictly based on alternative lifestyle and exclusive nourishment. Instead, most cooperatives, focused on the community aspect of the cooperative tradition, seem to neglect the individual aspect of the old cooperatives that is also rooted in Abramowski's thought. This includes individual economic benefits, on the one hand, but, on the other, the focus on the moral dimension of cooperation: not only self-fulfilment, but also commitment.

This is not the place to speculate whether the proposed evolution is probable; it is also not my intention to suggest that the intelligentsia must or should be leaders of 
the countermovement. An emergence of a successful countermovement could also happen elsewhere and it may be more effective with a different leadership. There are initial signs that some class alliances may be on the horizon. In 2016, the Dobrze cooperative supported the farmers' protest in Warsaw and was involved in fighting for a law to enable farmers to sell processed food directly to consumers. It is possible that cooperatives will yet become an important actor bringing together Polish food producers and urban consumers in a single countermovement. ${ }^{11}$

11 The initial version of this paper was given as a working Paper at the Max Planck Institute for Social Anthropology in Halle-Saale in 2017. I express my gratitude to Chris Hann and the members of the seminar of the Department 'Resilience and Transformation in Eurasia' at the Institute for their useful comments on this paper. I am also grateful to Steve Reyna and Mathijs Krul for their insightful comments. 


\section{References}

Abramowski, Edward. 2010. Kooperatywa. Polskie korzenie przedsiębiorczości społecznej. Ed. R. Okraska. Łódź: Stowarzyszenie "Obywatele Obywatelom."

Abramowski, Edward. 2013. Zagadnienia socjalizmu. Wybórpism. Kraków: Ośrodek Myśli Politycznej.

Alexander, Catherine. 2011. "Illusions of freedom. Polanyi and the third sector." In Market and society: The Great Transformation today. Eds. Ch. Hann and K. Hart. Cambridge: Cambridge University Press.

Bilewicz, Aleksandra and Dominika Potkańska. 2013. "Jak kiełkuje społeczeństwo obywatelskie? Kooperatywy spożywcze w Polsce jako przykład nieformalnego ruchu społecznego." Trzeci sektor 1(3): 25-44.

Bilewicz, Aleksandra and Ruta Śpiewak. 2015. "Enclaves of activism and taste: Polish consumer cooperatives as alternative food networks." Socio.bu 3. Special Issue in English on the Social Meaning of Food: 147-166.

Bilewicz, Aleksandra. 2017. Spotem. Idea, ludzie, organizacja. Tom 1. Warszawa: Oficyna Naukowa.

Block, Fred. 2003. "Karl Polanyi and the writing of Great Transformation." Theory and Society 32(3): 275-306.

Block, Fred and Margaret Somers. 2014. The power of market fundamentalism: Karl Polanyi's critique. Cambridge, Mass.: Harvard University Press.

Bressen, Tree. 2007. "Consensus decision making." Group Faciliation: A Research \& Application Journal 8: 381-392.

Brodziński, Marian. 1999. Dylematy rozwoju spółdzielczości w Polsce. Warsaw: Fundacja "Rozwój SGGW."

Brunori, Gianluca. 2007. "Local food and alternative food networks: a communication perspective." Anthropology of Food S2. Available online at: http://aof.revues.org/430 (accessed on April 28, 2015).

Bryant, Robert and Michael Goodman. 2013. Peopling the practices of sustainable consumption: eco chic and the limits of the spaces of intention. Environment, Politics and Development Working Paper Series 55. London: Department of Geography, King's College.

Carmony, Donald F. and Josephine M. Elliot. 1980. "New Harmony, Indiana: Robert Owen's seedbed for Utopia.” Indiana Magazine of History 76(3): 161-261.

Chałasiński, Jerzy. 1958. Præeszłość i praysszłość inteligencji polskiej. Warsaw: Ludowa Spółdzielnia Wydawnicza.

Chyra-Rolicz, Zofia. 1985. Pod spótdrielczym sztandarem: z dziejów spótdzielczości polskiej do 1982 r. Warszawa: Wydawnictwo Spółdzielcze.

Chyra-Rolicz, Zofia. 1992. Z tradycji spótdzielcrości II Rzueczpospolitej (idee, fakty, dokonania). Warszawa, Poznań: Ławica.

Dąbrowska, Maria. 1922. Spótdzielczość zwycieżajaca (dzieje angielskiej Hurtowni Stowarayszzeń Spożywców). Warszawa: Związek Polskich Stowarzyszeń Spożywców.

Dale, Gareth. 2013. Polanyi: the limits of the market. Cambridge, Malden: Polity Books.

Dale, Gareth. 2016. Reconstructing Polanyi: excavation and critique. London: Pluto Press.

Dale, Gareth. 2016b. Karl Polanyi. A Life on the Left. New York, Chichester: Columbia University Press.

Day, Richard 2005. Gramsci is dead: anarchist currents in the newest social movements. Toronto: Pluto Press and Between the Lines. 
Duszyk, Adam. 2007. Między idea a polityka: ruch spóldzielczyy centralnych riem polskich w XX wieku: studia. Radom: Radomskie Towarzystwo Naukowe.

Fairbairn, Bruce. 1994. "The meaning of Rochdale: the Rochdale pioneers and the cooperative principles." Occasional Paper Series No. 94.02. Saskatchewan: University of Saskatchewan. Centre for the Study of Co-operatives.

Frazer, Nancy. 2013. "A triple movement? Parsing the politics of crisis after Polanyi." New Left Review 81. Available online at: http://newleftreview.org/II/81/nancy-fraser-atriple-movement (accessed on October 11, 2014).

Freeman, Joe. 1971. "The Tyranny of Structurelessness.” Berkeley Journal of Sociology 17. Available online at: http://www.jofreeman.com/joreen/tyranny.htm (accessed on September 19, 2017).

Gide, Charles. 1922. Consumers' cooperative societies. Binghamton, NY: Alfred A. Knopf.

Graeber, David. 2002. "The new anarchists." New Left Review 13. Available online at: https://newleftreview.org/II/13/david-graeber-the-new-anarchists (accessed on September 19, 2017).

Giełżyński, Wojciech. 1986. Edward Abramowski. Zwiastun Solidarności. London: Polonia. Goodman, David and Michael Goodman. 2009. "Alternative food networks." In Encyclopedia of Human Geography. Eds. R. Kitchen and N. Thrift. Amsterdam, Boston, Heidelberg, London: Elsevier.

Goody, Jack. 1982. Cooking, cuisine and class: a study in comparative sociology. Cambridge: Cambridge University Press.

Hann, Chris. 1992. "Radical functionalism: the life and work of Karl Polanyi." Dialectical Anthropology 17(2): 141-166.

Hann, Chris and Keith Hart. 2011a. Economic anthropology: bistory, ethnography, critique. Cambridge: Polity Press.

Hann, Chris and Keith Hart. 2011b. "Introduction: learning from Polanyi 1." In Market and society: The Great Transformation today. Eds. Ch. Hann and K. Hart. Cambridge: Cambridge University Press.

Hettne, Björn. 1990. "The contemporary crisis: the rise of reciprocity." In The life and work of Karl Polanyi: a celebration. Ed. K. Polanyi Levitt. Montreal, New York: Black Rose Books.

Hettne, Björn. 2006. "Re-reading Polanyi: a second Great Transformation?" In Karl Polanyi in Vienna: the contemporary significance of The Great Transformation. Eds. K. McRobbie and K. Polanyi Levitt. Montreal, New York, London: Black Rose Books.

Holyoake, George. 1908. The history of cooperation. London: T. Fisher Unwin.

Horton, David. 2003. "Green distinctions: the performance of identity among environmental activists." The Sociological Review 51: 63-77.

Jossa, Bruno. 2005. "Marx, Marxism and the cooperative movement." Cambridge Journal of Economics 29(1): 3-18.

Kazmierczak, Tadeusz and Marek Rymsza. 2008. Social economy in Poland: past and present. Warsaw: Institute of Public Affairs.

Knupfer, Anne Meis. 2013. Food coops in America: communities, consumption and economic democracy. Ithaca, London: Cornell University Press.

Kowalik, Tadeusz. 1991. "The Polish postscript, 1989.” In The legacy of Karl Polanyi: market, state and society in the end of the twentieth century. Eds. M. Mandell and D. Salée. Quebec: Concordia University.

Krzywicki, Ludwik. 1903. Stowarzyszenia spożywcze: ustepp z driejów kooperacji. Warszawa: Nakł. Członków Stowarzyszenia Spożywczego Kolei Warszawsko-Wiedeńskiej. 
Mendell, Marguerite. 2006. "Democratizing capital: alternatives to market-led transition." In Karl Polanyi in Vienna: the contemporary significance of The Great Transformation. Eds. K. McRobbie and K. Polanyi Levitt. Montreal: Black Rose Books.

Melucci, Alberto. 1989. Nomads of the present: social movements and individual needs in contemporary society. London: Hutchison Radius.

Mielczarski, Romuald. 2010. Razem! Cayyli Spotem. Wybór pism spółdzielczyych. Ed. R. Okraska. Łódź, Sopot, Warszawa: Biblioteka "Obywatela."

Miele Mara and Jonathan Murdoch. 2004. "A new aesthetic of food? Relational reflexivity in the »alternative food « movement". In Qualities of Food. Eds. M. Harvey, A. McMeekin and A. Warde. Manchester: Manchester University Press.

Peisert, Arkadiusz. 2009. Spótdrielnie mieszkaniowe. Międry wspólnota obywatelska a alienacja. Warszawa: IFiS PAN.

Piechowski, Adam. 1999. "Non-cooperative cooperatives: new fields for cooperative and quasi cooperative system in Poland." Review of International Cooperation 92(1): 49-57.

Polanyi, Karl. 1968a. "Our obsolete market mentality." In Primitive, archaic and modern economies: essays of Karl Polanyi. Ed. G. Dalton. Boston: Beacon Press.

Polanyi, Karl. 1968b. "Aristotle discovers the economy." In Primitive, archaic and modern economies: essays of Karl Polanyi. Ed. G. Dalton. Boston: Beacon Press.

Polanyi, Karl. 1968c. "Class interest and social change." In Primitive, archaic and modern economies: essays of Karl Polanyi. Ed. G. Dalton. Boston: Beacon Press.

Polanyi, Karl. 1977. "Forms of integration and supporting structures." In The livelihood of man. Ed. H.B. Pearson. New York, San Francisco, London: Academic Press.

Polanyi, Karl. 2001 [1944]. The Great Transformation: the political and economic origins of our time. Boston: Beacon Press.

Rapacki, Marian. 1923. “Socjalizm i kooperacja.” Rzeczpospolita spółdrielcza 12(III): 505-509.

Rose, Fred. 1997. "Toward a class cultural theory of new social movements: reinterpreting new social movements." Sociological Forum 12(3): 461-494.

Rusiński, Władysław. 1967. Zarys historii polskiego ruchu spótdzielczego. Cz̨ść II: 1918-1939. Warszawa: Zakład Wydawniczy CZSR.

Sennett, Richard. 2012. Together: the rituals, pleasures and politics of cooperation. New Haven, London: Yale University Press.

Siwik, Bronisław. 1923. "Spółdzielczość a socjalizm.” Rzeczpospolita spółdrielcza 11(III): 457463.

Stryjan, Yohanan. 1994. "Understanding cooperatives: the reproduction perspective." Annals of Public and Cooperative Economics 65(1): 59-80.

Stryjan, Yohanan and Filip Wijkström. 1996. "Cooperatives and nonprofit organizations in Swedish social welfare." Annals of Public and Cooperative Economics 67(1): 5-27.

Szelényi, Ivan. 1982. "The intelligentsia in the class structure of state socialist societies." The American Journal of Sociology 82: S287-S326.

Vieta, Marcelo. 2010. "The new cooperativism." Affinities: A Journal of Radical Theory, Culture and Action 4(1): 1-11.

Webb, Beatrice. 1930. Cooperative movement in Great Britain. London: George Allen \& Unwin.

Winter, Michael. 2003. "Embeddedness, the new food economy and defensive localism." Journal of Rural Studies 19(1): 23-32.

Wedel, Janine. 1986. The private Poland: an anthropologist's look at everyday life. New York, Oxford: Facts on File Publications.

Wojciechowski, Stanisław. 1938. Moje wspomnienia. Vol. 1. Lwów-Warszawa: Książnica-Atlas. 
Zarycki, Tomasz. 2003. "Cultural capital and the political role of the intelligentsia in Poland." Journal of Communist Studies and Transition Politics 19(4): 91-108.

Zarycki, Tomasz. 2009. "The power of the intelligentsia: the Rywin affair and the challenge of applying the concept of cultural capital to analyze Poland's elites." Theory and Society 38: 613.

Zarycki, Tomasz. 2014. "Social dialogue under the supremacy of the intelligentsia." Warsaw Forum of Economic Sociology 5:2(10): 69-78.

Zarycki, Tomasz, Rafał Smoczyński, and Tomasz Warczok. 2017. "The roots of Polish culture-centered politics: Toward a non-purely cultural model of cultural domination in Central and Eastern Europe." Eastern European Politics and Societies and Cultures 31(2): 360-381.

Żarnowski, Jerzy. 1964. Struktura społeczna inteligencï w Polsce w latach 1918-1939. Warsaw: PWN. 
Aleksandra Bilewicz - studied philosophy and sociology at the University of Warsaw and the Freie Universitaet in Berlin. She defended her Phd on the new consumer cooperative movement in Poland from the perspective of economic anthropology at the Institute of Sociology, University of Warsaw. She is currently co-editing (together with Bartłomiej Błesznowski) a series of books devoted to reviving the memory of Polish cooperative thought and practice ("Kooperatyzm"). She is the author of Spotem 1906-1939: Idea, ludrie, organizacja (Spotem 1906-1939: Idea, people and institution).

\author{
ADRESS: \\ Aleksandra Bilewicz \\ Instytut Studiów Społecznych, Uniwersytet Warszawski \\ ul. Stawki 5/7 \\ 00-183 Warszawa
}

E-MAIL: ambilewicz@gmail.com

CITATION: Bilewicz, Aleksandra. 2018. "A Path to a Countermovement? Forms of Integration in Polish Consumer Cooperatives." Praktyka Teoretyczna 1(27): 133-167.

DOI: $10.14746 /$ prt.2018.1.6

Aleksandra Bilewicz - studiowała socjologię i filozofię w ramach Międzywydziałowych Studiów Humanistycznych na Uniwersytecie Warszawskim. W Instytucie Socjologii UW obroniła doktorat na temat nowych polskich kooperatyw spożywczych ujmowanych z perspektywy antropologii ekonomicznej. Wraz z Bartłomiejem Błesznowskim redaguje serię naukową „Kooperatyzm”, której celem jest przybliżenie zapomnianej polskiej idei i praktyki spółdzielczej. Autorka dwutomowej pracy Społem 1906-1939. Idea, ludzie, organizacja.

TYTUL: W stronę samoobrony społeczeństwa? Ekonomiczne formy integracji w polskich kooperatywach spożywczych

ABSTRAKT: Niniejszy artykuł stanowi analizę polskich kooperatyw spożywczych przy użyciu kategorii wypracowanych przez Karla Polanyi'ego - autora pojęcia gospodarki zanurzonej społecznie („embedded economy”). W artykule dokonano porównania „nowych” kooperatyw - nieformalnych grup konsumentów powstających w Polsce od 2010 roku z „dawnym” ruchem spółdzielni spożywców, który rozwijał się w Polsce między 1906 a 1939 rokiem, reprezentowanym przede wszystkim przez Związek „Społem”. Podążaąc za tym, jak Polanyi rozumiał związek między gospodarką a instytucjami społecznymi, autorka analizuje 
wzajemność i redystrybucje jako formy integracji ekonomicznej (według Polanyi’ego: „forms of economic integration”) w dawnych i nowych kooperatywach spożywczych. Mimo że „nowe” kooperatywy odwołują się do spółdzielczej tradycji, okazuje się, że ich struktura i sposób gospodarowania różnią się znacznie od tego, jak funkcjonowały oryginalne spółdzielnie spożywców oparte na modelu roczdelskim. Autorka argumentuje na rzecz tezy, że struktura nowych kooperatyw spożywczych nie pozwala ustanowić wzajemności i symetrii, które Polanyi uznawał za mechanizmy konieczne do funkcjonowania gospodarki zanurzonej społecznie. W artykule poruszona zostaje również kwestia barier klasowych w „dawnych” i „nowych” kooperatywach - posługując się pojęciem samoobrony społecznej, zaproponowanym przez autora Wielkiej transformacji, autorka zadaje pytanie o możliwość zbudowania szerszego ruchu społecznego na bazie współczesnych kooperatyw.

SLOWA KLUCZOWE: kooperatywy spożywcze, gospodarka zanurzona społecznie, formy integracji, wzajemność, samoobrona społeczeństwa, Karl Polanyi. 